\title{
The Impact of European Green Deal on Turkey's Iron and Steel Industry: Decomposition Analysis of Energy-Related Sectoral Emissions
}

\author{
Abdulkadir Bektaş ${ }^{1 *}$ (iD) \\ ${ }^{1}$ The Ministry of Energy and Natural Resources, Nasuh Akar Mah. Türk Ocağ 1 Cad. \\ No: 206520 Cankaya - Ankara, Turkey \\ *kadirbektas35@gmail.com \\ *Orcid: 0000-0003-0199-2251 \\ Received: 8 November 2020 \\ Accepted: 1 March 2021 \\ DOI: $10.18466 /$ cbayarfbe. 823265
}

\begin{abstract}
The European Union has put forward a vision under the EU Green Deal's name to take the lead in its priorities, fulfill the Agreement's criteria, and subsequently accept the first EU climate law on March 5, 2020. The law framework aims to impose tax obligations on consumption goods imported by the EU from abroad, especially on energy-intensive sectors, by applying the carbon border adjustment mechanism. Our main goal is to determine what kind of measures can be taken to ensure that the iron and steel industry is least affected by the EU border carbon regulation. We are an absolute exporter, are least affected by the EU carbon border adjustment. For this reason, the change in energy-related greenhouse gas emissions from the iron and steel industry from 1998 to 2018 was analyzed using the Logarithmic Mean Divisia Index (LMDI) model to investigate the potential effects of carbon border adjustment in the iron and steel industry. The analyzes were made with five significant factors that determine the change of emissions. These factors are; changes in economic activity, activity mix, energy intensity, energy mix, and emission factors. Analysis has suggested that the economic activity effect has raised $\mathrm{CO} 2$ emissions. This method indicates that the energy intensity's impact could be the first key determinant of GHG emissions. Turkey should attempt to implement low-carbon development policies and reduce energy-related emissions in the iron \& steel sector are the least impacted by the EU's carbon border adjustment.
\end{abstract}

Keywords: Carbon Border Adjustment, Decomposition Analysis, Energy, Greenhouse Gas Emissions, Iron and Steel Industry.

\section{Introduction}

Today, the phenomenon of climate change, which shows its effects in the form of excessive rainfall, floods, and extreme temperatures, has been one of the priority issues in the European Union, as in the whole world. The adverse effects of climate change have been primarily observed on agriculture and food security, water resources, public health, land and marine ecosystems, and coastal regions. The Special Report of the Intergovernmental Panel on Climate Change (IPCC) on the effects of global warming above $1.5^{\circ} \mathrm{C}$ of preindustrial levels confirms that the global effects of climate change increase with the average global temperature. Furthermore, the dramatic effects would be seen worldwide in $2{ }^{\circ} \mathrm{C}$ due to climate change. European Union accelerated its efforts to take more precautions and reduce these impacts on combating climate since it considers climate change an urgent problem due to the severe disasters in the world ecosystem, biodiversity, health, and food system.

The Paris Agreement aims to keep global temperature rise well below $2^{\circ} \mathrm{C}$ and take measures to keep it at 1.5 ${ }^{\circ} \mathrm{C}$. Its aim is to become carbon-neutral (zero-emission) by the middle of this century. As stated in the IPCC report [1], to limit the temperature increase to 1.5 , netzero $\mathrm{CO} 2$ emissions at the global level should be achieved around 2050, and neutrality should be ensured for all other greenhouse gases later in the century. In this context, the European Union put forward a vision on December 11, 2019, in the name of the European Green Deal (EGD) to take the lead in terms of its interests and fulfill the Paris Climate Agreement's requirements [2]. The European Commission, in this new growth plan, is committed to becoming the world's first climate-neutral bloc by 2050 . This plan also aims to transform the EU into a fair and prosperous society where greenhouse gas emissions are net zero in 2050 . 
The decoupling of economic growth and resource use has been achieved based on a modern, climate-neutral, resource-efficient, and competitive economic structure. In the transition into a climate-neutral economy, the industry has a prominent key role. All manufacturing value chains, including energy-intensive industries, would face the main challenges. In March 2020, the European Commission proposed "A New Industrial Strategy for Europe." This document underpins the essential role of industry in the transition towards a carbon-neutral economy. The industry needs to reduce its carbon footprints, offer accessible, clean technology solutions, and create new business models to accelerate the transition.

The European Green Deal is a new growth strategy for the European Union that would provide more gain than they would spend. It is a vision that includes making the EU economy a global leader while meeting the Paris Agreement's long-term emission targets by taking advantage of the opportunities obtained in this way. For this purpose, the EU has announced that it would implement various applications in many areas. "Carbon border adjustment mechanism," which the EU plans to implement against commercial partners in 2021, is its most important application, which would profoundly affect our trade with the EU since the EU is our most important export and import partner [3]. The EU aims to impose a severe tax liability on imported products, primarily to energy-intensive sectors. Therefore, energy-intensive sectors would be severely affected, such as steel, cement, glass, and aluminum.

The EU green deal strategy would have a direct effect on trade ties with the Turkish bloc and this can be used to turn efficient infrastructure in the country. As a developing country, Turkey needs increasing amounts of energy demand. The main policy objective is to maintain its energy supply and keep up with the demand to support its economic growth as its population increases. It needs to urgently transform its energy system to reduce its reliance on imports, which constitute 3 out of 4 units of total primary energy supply. With an increasing economy and population, the country's imported energy costs have reached unprecedented levels, driving a large proportion of Turkey's current account deficit. Therefore, Turkey also wants to use hydrocarbons that are its domestic capital. In this respect, greenhouse gas emissions that cause global warming need to be analyzed in detail based on sectors that are likely to be subject to carbon border regulation. Emissions originated from the iron and steel industry, which is one of the intensive energy sectors and of which we are an absolute exporter, would be examined. Our main objective is to decide what kind of steps can be taken to ensure that the EU border carbon regulation is least impacted on the iron and steel industry. Logarithmic Mean Divisia Index (LMDI) method has been used to decompose changes in GHG emissions for the iron and steel industry from 19982018. It is used to decompose GHG emissions into five driving forces in the iron and steel industry; changes in economic activity, activity mix, energy intensity, energy mix, and emission factors (EF). Four types of fuel were used in the analyzes; solid, liquid, gas, and other fuels. The biomass fuel type was not considered, as $\mathrm{CO}_{2}$ emissions from biomass were not included in the total $\mathrm{CO}_{2}$ emissions from fuel combustion. The results have shown that 1 ) the economic activity impact (GDP) is the most critical determining factor behind the change in $\mathrm{CO} 2$ emissions. 2) Similarly, the sectoral energy structure also had an increasing effect on emissions, and 3) energy density, energy composition, and emission factors have a decreasing effect on emissions.

\section{European Green Deal}

The European Commission presented "The European Green Deal," which reveals the European Union's new strategic vision for 2050 with the perspective of "combating climate change and economic growth" and includes regulations that concern almost all sectors in December 2019. It is a long-term strategic vision for a thriving, prosperous, competitive, and climate-neutral economy by 2050 . The strategy demonstrates how, by investing in real technical solutions, motivating people, and associating activity in critical areas such as industrial policy, finance, or science, Europe can lead the way to climate neutrality while maintaining social justice for a just transition. The EU has indeed begun modernizing and changing the economy with a goal of climate neutrality. It decreased greenhouse gas emissions by $23 \%$ between 1990 and 2018, while the economy expanded by $61 \%$. There are severe breakthroughs in energy efficiency and renewable energy in achieving this success. As expected by the Paris Agreement, the European Union intends to reduce its emissions by 40 percent by 2030, update the 2030 target to 55 percent with the European Green Deal, and meet a reduction target of 100 percent as set out in the 2050 target. Achieving a 55 percent reduction in greenhouse gas emissions would take measures in all economic sectors. A climate-neutral transition can be done only with the contributions of everybody. The EU Parliament approved an amendment that increased this target to $60 \%$ on October 7 .

The Commission estimates that meeting the current environment and energy goals for 2030 would require an additional EUR 260 billion of annual investment, about 1.5 percent of GDP in 2018. Apart from the current 2030 and 2050 emission targets, the "Green Deal for Europe" requires additional funding. In response to the additional financing requirement, it is stated that the European Commission would present the "Sustainable Investment Plan for Europe." As part of the plan, it is envisaged to establish a "Just Transition Fund," the "Just Transition Fund," and a Just Transition 
Mechanism of $€ 100$ billion. As part of the Green Deal, the Commission presented on January 14, 2020, a European Green Deal Investment Plan of at least $€ 1$ trillion over the next decade to stimulate sustainable investment. Green Deal consists of 47 actions under the main headings of Climate, Energy, Industry, Transportation, Agriculture, Biodiversity, Environmental Pollution, Financing, Leadership, and Working Together. Based on the point that the specified comprehensive transformation cannot be achieved only by Europe's efforts, the EU intends to lead international studies in this direction; it is observed that it aims to encourage its partners to take similar steps by sharing its expertise, and financial resources. Since the driving factors that cause climate change and biodiversity exceed national borders, “The Green Consensus' gear up in terms of the environmental target cannot be achieved by Europe acting alone. Therefore, it aims to share its dialogue, expertise, and financial support with neighboring and partner countries at the EU cooperation point. On the other hand, to avoid being disadvantaged in international competition and prevent carbon leakage, the European Union foresees significant changes in its foreign trade and international investment and financing policies. These changes can be listed with the following subtitles;

1- Failure to sign new free trade agreements with countries that do not ratify the Paris Agreement

2- Carbon border adjustment mechanism

3- Funding

4- Standards and eco-labeling

According to the Green Deal, the EU requires the candidate country to "ratify and effectively implement the Paris Agreement" for liberalization agreements, such as the free trade agreement it would make with other countries. The text considers ratification sufficient for the country to be a member but goes further and suggests a condition of practical implementation.

\subsection{Green Deal Evaluation in Turkey-EU Trade: Carbon Border Regulation}

The European Union (EU), consisting of 27 countries, is the world's largest political and economic organization. Although it constitutes about $7 \%$ of the world population, the EU is among the world's largest economic and trade actors. In addition to this, the EU is a significant market for our country with its large and diversified market structure, advanced infrastructure opportunities, technical standards, and health measures applied in the same way in all member countries, current market size, and future trade potential. When the EU is considered a single block, it ranks second in world exports and imports of goods, taking $15.2 \%$ of world goods exports and $14.7 \%$ of world imports. With a trade surplus of $\$ 209$ billion in service trade, the EU is the world's largest exporter and importer. With an intense and diversified market structure, the EU offers our exporters countless opportunities at every stage of the value chain by importing essential products such as agricultural products, raw materials, and energy and importing investment chemical and various consumer goods. Having an import volume of approximately 2.1 trillion dollars, the EU is increasing its import volume in many sectors day by day. With this import size, these sectors offer a tremendous market opportunity to our exporters.

For all these reasons, the "carbon border adjustment mechanism," which the EU plans to implement against commercial partners in 2021, stands as the most critical topic. In case the worldwide differences in climate action persist, it is aimed to create a carbon regulation mechanism at a new frontier in combating the risk of carbon leakage. With this mechanism, it is envisaged to ensure that the goods imported into the EU under the World Trade Organization rules and other international obligations of the EU are priced to reflect their carbon content [3]. In short, it is understood that this EGD implementation, which would cause the most significant impact on a global scale, has been taken against countries that do not take obligations to protect the EU from the competition and to prevent carbon leaks. The EU imposes strict obligations on carbon-intensive businesses to be carbon neutral while pricing the carbon through the European Union Emission Trading System (EU ETS) and charging these businesses' costs. EU companies and environmentalists criticized that a country business with no emission obligation abroad exports the same type of goods to the EU without any cost.

Moreover, since it is costly to produce such products within the EU due to the carbon price, buying the same product by importing from a country with no abatement obligation does not mean that the obligating EU country reduces its emissions. (For example, steel is cheaper to import from Turkey came to an automobile company in Germany) Such consequences, called carbon leakage, could increase global emissions since the importer country (Germany in the example) was not deducted from its emissions. Therefore, in recent years, EU countries have focused primarily on reducing consumption-based emissions and production. In this sense, the border carbon adjustment mechanism can solve both problems [4]. This framework recommends the "carbon border adjustment mechanism" to reduce carbon leakage caused by exports in selected carbonintensive sectors. In other words, the EU seeks to defend its carbon pricing market and its export leakage to different countries while pursuing more ambitious emission reduction goals. It also needs to keep commodity prices competitive against substitution for imported goods, increasing jobs by reducing imports. 
In particular, the EU would like to give priority the mining (coal, iron and steel, petroleum, chemical, and fertilizer raw materials) and sugar, malt, textile, glass, paper, plastic, ceramic, cement, steel, sectors as those that may be exposed to carbon leakage. It is understood that they have targets, such as creating funds and additional investments for the revenues to be generated by these mechanisms.

As the EU is the world's largest trade bloc with a nonEU trade figure of around 3.9 trillion euros, the border tax regulation can have severe global impacts. Half of the foreign trade with EU member states such as Turkey, a country that this application would be greater than the effect of the form. To be established on January 1, 1996, together with the Customs Union trade volume between Turkey and the EU gained momentum in 2019, 161.6 billion dollars (exports: $\$ 88.0$ - imports: \$ 73.5) as incurred and most of our EU countries has continued to be an essential trading partner. $4 \%$ of the total EU exports to Turkey were made. The EU has a share of $48.7 \%$ in our exports with 88.0 billion dollars in 2018 and ranks first in our total exports. Our country has a share of $4 \%$ of the total imports in the EU. Besides, the EU ranks first in imports as well as in our country's exports. According to 2019 figures, Turkey 210.3 billion dollars to 73.5 billion dollars of the total imports of goods (35.0\% share) were realized from the EU. In 2019 , the ratio of exports to imports in our country's trade with the EU was $119.7 \%$.

Table- 1 shows the import-export with the EU beetween 2013-2019.

The 'iron-steel, aluminum, cement, glass, and ceramic' industries are among the energy-intensive sectors and are considered to be affected by the policy changes envisaged by the EU under the European Green Deal (EGD), are expected to be included in the list. Because $75 \%$ of the EU's carbon emissions come from the energy sector, the energy sector's transformation is expected to form the Green Deal's backbone, which would also be a prerequisite for decarbonizing other sectors. Considering that our exports to the EU in products and services with a high risk of carbon leakage (COMMISSION et al., 2019) are at the level of 28.2 billion dollars, the issue should be addressed and protected in our country holistically. Improving the competitiveness of our exporters in the EU market is considered essential. Due to Turkey's developing country, there is an increasing amount of energy demand.

Table 1. Our foreign trade with the European Union (Billion US \$)

\begin{tabular}{|c|c|c|c|c|c|c|c|c|}
\hline EU (28) & Foreign Trade & 2019 & 2018 & 2017 & 2016 & 2015 & 2014 & 2013 \\
\hline Total exports & & 180,8 & 177,2 & 164,5 & 149,2 & 151,0 & 166,5 & 161,5 \\
\hline Total imports & & 210,3 & 231,2 & 238,7 & 202,2 & 213,6 & 251,1 & 260,8 \\
\hline \multirow{7}{*}{$\begin{array}{l}\text { A-European Union } \\
\text { (E.U. 28) }\end{array}$} & Export & 88,0 & 88,9 & 77,9 & 71,9 & 67,3 & 72,4 & 67,4 \\
\hline & $\%$ export & $48,7 \%$ & $50,2 \%$ & $47,4 \%$ & $48,2 \%$ & $44,6 \%$ & $43,5 \%$ & $41,7 \%$ \\
\hline & Import & 73,5 & 84,7 & 88,8 & 80,7 & 82,6 & 93,3 & 96,9 \\
\hline & $\%$ import & $35,0 \%$ & $36,6 \%$ & $37,2 \%$ & $39,9 \%$ & $38,7 \%$ & $37,2 \%$ & $37,1 \%$ \\
\hline & $\begin{array}{l}\text { Foreign trade } \\
\text { volume }\end{array}$ & 161,6 & 173,6 & 166,7 & 152,7 & 149,9 & 165,7 & 164,2 \\
\hline & Export-Import & 14,5 & 4,2 & $-10,9$ & $-8,8$ & $-15,3$ & $-21,0$ & $-29,5$ \\
\hline & Coverage Rate & $120 \%$ & $105 \%$ & $88 \%$ & $89 \%$ & $81 \%$ & $78 \%$ & $120 \%$ \\
\hline
\end{tabular}

According to National Energy and Mines, it is required to use hydrocarbons in the domestic capital position. In this respect, it can be stated that there are essential steps to be taken in EGD and climate change. To carry out the necessary studies in this area, greenhouse gas emissions that cause global warming should be analyzed in detail based on sectors that are likely to be subject to border carbon regulation.

\subsection{Development of Turkey's energy-related GHG Emissions}

According to the Turkish Statistical Institute, Turkey's total greenhouse gas emissions in 2018 are 520.9 million tons (Mt) of $\mathrm{CO} 2$ equivalent. This value represents an increase of $240.7 \mathrm{Mt} \mathrm{CO} 2$ equivalent, with an increase of 86 percent compared to 1998 [5]. Population growth, the growing economy, and the increase in demand for energy are among the main reasons for increased emissions. While energy-related emissions had the highest share in total emissions with 71.6 percent, this rate was only $0.8 \%$ for the iron and steel industry. Turkey showed increased emissions during the period mentioned in terms of both quantity and proportionate emissions from the iron and steel sector has shown a downward trend. This tendency shows us that the iron and steel industry is taking firm steps towards becoming a cleaner, lower-emission sector on an annual basis. Sectoral emissions based on years are given in detail in Table-2. 
Table 2. The energy-related greenhouse gas emissions in Turkey, $\mathrm{kt} \mathrm{CO}_{2}$ eq. (1998-2018)

\begin{tabular}{lcccccc}
\hline Years & $\begin{array}{c}\text { Total } \\
\text { Emissions }\end{array}$ & Energy Sector & $\begin{array}{c}\text { Manufacturing } \\
\text { Industry and } \\
\text { Construction }\end{array}$ & $\begin{array}{c}\text { Iron and Steel } \\
\text { Sector }\end{array}$ & $\begin{array}{c}\text { Transport } \\
\text { Sector }\end{array}$ & $\begin{array}{c}\text { Other } \\
\text { Energy } \\
\text { Sectors }\end{array}$ \\
\hline 1998 & 280231 & 195864 & 55470 & 6152 & 32782 & 37704 \\
1999 & 277650 & 193817 & 47365 & 5576 & 34617 & 35753 \\
2000 & 298760 & 216054 & 57936 & 6566 & 36465 & 37764 \\
2001 & 280301 & 199233 & 45656 & 6732 & 36455 & 31397 \\
2002 & 286003 & 205832 & 57112 & 6461 & 36234 & 32930 \\
2003 & 305261 & 220300 & 66682 & 6197 & 37825 & 36232 \\
2004 & 314669 & 226139 & 63857 & 5057 & 42048 & 39561 \\
2005 & 337140 & 243965 & 63004 & 5482 & 42041 & 42709 \\
2006 & 358292 & 259959 & 70084 & 4524 & 45424 & 42236 \\
2007 & 391422 & 290771 & 71874 & 4640 & 52099 & 45279 \\
2008 & 387590 & 287279 & 47354 & 3977 & 48166 & 64410 \\
2009 & 395596 & 292501 & 46226 & 2912 & 47907 & 70959 \\
2010 & 398883 & 287047 & 52332 & 2644 & 45392 & 67773 \\
2011 & 427831 & 308666 & 52585 & 3990 & 47386 & 74656 \\
2012 & 447255 & 320489 & 61052 & 4298 & 62525 & 61586 \\
2013 & 439326 & 307523 & 52978 & 4638 & 68865 & 56384 \\
2014 & 458369 & 325767 & 54438 & 4992 & 73559 & 56079 \\
2015 & 472595 & 340907 & 59585 & 5288 & 75798 & 65327 \\
2016 & 497742 & 359671 & 60071 & 4190 & 81841 & 65201 \\
2017 & 523753 & 379901 & 60180 & 4327 & 84659 & 73391 \\
2018 & 520942 & 373101 & 59578 & 4215 & 84502 & 62868 \\
Difference & 240.711 & 177.237 & 93.326 & 4.108 & -1.937 & 51.719
\end{tabular}

Table-2 and Figure-1 show that the total emissions $(85.9 \%)$ and energy sector emissions $(90.5 \%)$ increased significantly between 1998-2018. One of the most important reasons behind this increase is considerable GDP development (Million \$ at current prices), which increased by $184.4 \%$ in the same period. During the same period, the average GDP growth was 4.6. The economic growth effect increases the demand for energy, which naturally causes a severe increase in energy-related emissions. While the share of the iron and steel industry in GDP increased from 1.3 percent to 3.2 percent in the specified period, it corresponds to a considerable increase of $575.8 \%$ in terms of the value it creates.

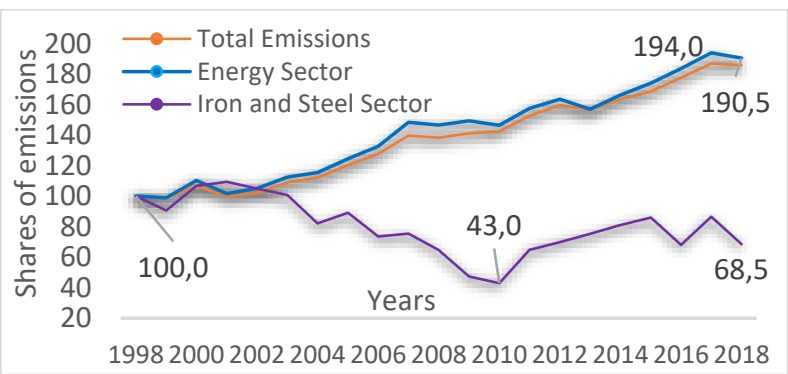

Figure 1. The change of energy-related sectoral emission shares, 1998-2018
In the same period, sectoral energy intensity decreased by 68 percent, followed by a 31.5 percent decrease in emissions. Detailed data are given in Table-3.

Table 3. The development of the indicators of the iron and steel industry by years (1998-2018)

\begin{tabular}{cccc}
\hline Years & $\begin{array}{c}\text { Iron and Steel } \\
\text { Industry } \\
\text { Emissions Rate } \\
(\boldsymbol{\%})\end{array}$ & $\begin{array}{c}\text { Share of } \\
\text { GDP } \\
\mathbf{( \% )}\end{array}$ & $\begin{array}{c}\text { Energy } \\
\text { intensity } \\
\text { (toe/1000 \$) }\end{array}$ \\
\hline 1998 & $2,2 \%$ & $1,3 \%$ & 1,07 \\
1999 & $2,0 \%$ & $1,2 \%$ & 1,22 \\
2000 & $2,2 \%$ & $1,2 \%$ & 1,33 \\
2001 & $2,4 \%$ & $1,5 \%$ & 1,21 \\
2002 & $2,3 \%$ & $1,4 \%$ & 1,22 \\
2003 & $2,0 \%$ & $1,5 \%$ & 0,95 \\
2004 & $1,6 \%$ & $1,9 \%$ & 0,56 \\
2005 & $1,6 \%$ & $1,8 \%$ & 0,50 \\
2006 & $1,3 \%$ & $2,1 \%$ & 0,39 \\
2007 & $1,2 \%$ & $2,4 \%$ & 0,32 \\
2008 & $1,0 \%$ & $3,1 \%$ & 0,23 \\
2009 & $0,7 \%$ & $2,0 \%$ & 0,39 \\
2010 & $0,7 \%$ & $2,1 \%$ & 0,38 \\
2011 & $0,9 \%$ & $2,9 \%$ & 0,29 \\
2012 & $1,0 \%$ & $2,7 \%$ & 0,29 \\
2013 & $1,1 \%$ & $2,5 \%$ & 0,30 \\
2014 & $1,1 \%$ & $2,5 \%$ & 0,30 \\
2015 & $1,1 \%$ & $2,2 \%$ & 0,39 \\
2016 & $0,8 \%$ & $2,0 \%$ & 0,45 \\
2017 & $1,0 \%$ & $2,6 \%$ & 0,39 \\
2018 & $0,8 \%$ & $3,2 \%$ & 0,34 \\
& & &
\end{tabular}




\subsection{Turkey's Iron and Steel Industry Structure}

Three integrated iron and steel manufacturing plants are currently operating in Turkey (Ereğli, İskenderun ve Karabük). There are 31 electric arc furnace mills operating in Turkey in addition to these plants.

As of 2018, 39.4 million tons of 51.8 million tons of crude steel capacity belongs to facilities producing from scrap and 12.4 million tons from iron ore [6]. In recent years, steel production and consumption, another major steel producer that decompose in the country's positive direction, Turkey in 2007-2012, among the top 15 steel producers in the country, after China and India, increasing fastest production 3. In 2011 and 2012, after achieving the country's position with the fastest increase in production, production decreased for three consecutive years in the 2013-2015 period. Turkey's crude steel production in 2015 , by $7.4 \%$, down from 34.04 million tons, down 31.52 million tons recovery in 2016 and 2017, starting with Turkey, crude steel production in 2018; It has managed to rank 2nd in Europe and 8th in the world (Figure-2).

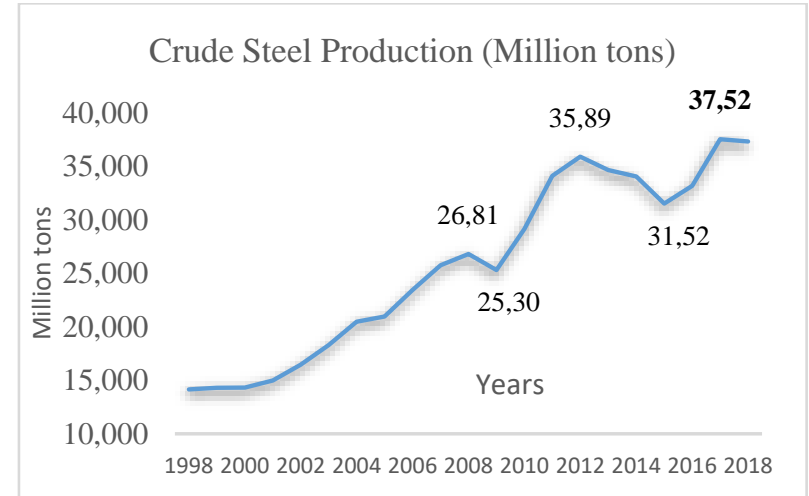

Turkey's crude steel production in August 2020 totaled 3.2 million tons, an increase of $22.9 \%$ compared to the same month of the previous year. In the January-August period, crude steel production increased by $0.6 \%$ to 22.7 million tons.

The sector reached the Capacity Utilization Rate in 2018 at the level of $71.9 \%$. In 2018, 19.5 million tons of iron and steel were exported, and 11.1 billion dollars of income was provided to our country. This figure corresponds to $6.6 \%$ of our total exports [6]. In 2018, the highest exports were made to EU countries $(9.062$ thousand tons; 7.840 million). The primary indicators related to the sector are given in Table- 4 .

Despite all the contractionary impact of the pandemic period, the Turkish steel sector to ensure the first eight months as a $0.6 \%$ production increase in production and a $13 \%$ increase in a show of Turkey's steel consumption has increased optimistic expectations for the final months of the year. However, in our domestic market, $50 \%$ of the consumption is met with imports, reducing capacity utilization rates. Consequently, the increase in consumption is not fully reflected in domestic production. On the other hand, the practices of the EU Commission continue to restrict our steel exports. While talking about quota restriction, dumping investigation, non-tariff transaction tax, it is now seen that EUROFER has requested tax implementation for the past years. On the other hand, the practices of the EU Commission continue to restrict our steel exports. While talking about quota restriction, dumping investigation, nontariff transaction tax, it is now seen that EUROFER has requested tax implementation for the past years.

Figure 2: The Value Created by the Steel Industry, 1998-2018

Table 1. The basic indicators for Turkey iron and steel industry ([6])

\begin{tabular}{|c|c|c|c|c|}
\hline Indicators & Unit & 2016 & 2017 & 2018 \\
\hline Industrial Sector Total Energy Consumption & ktoe & $33.253,7$ & $35.318,3$ & $36.155,0$ \\
\hline Iron and Steel Industry Energy Consumption & ktoe & $7.629,5$ & $8.540,8$ & $8.490,4$ \\
\hline Share of Iron and Steel Industry & $\%$ & 22,9 & 24,2 & 23,5 \\
\hline Specific Energy Consumption & tep/tons & 0,230 & 0,228 & 0,229 \\
\hline Crude Steel Production & million tons & 33.163 & 37.524 & 37.312 \\
\hline \multirow{2}{*}{ Iron and Steel Export } & million tons & 15.081 & 16.275 & 19.748 \\
\hline & Billion (\$) & 6.921 & 9.172 & 11.051 \\
\hline \multirow{2}{*}{ Iron and Steel Import } & million tons & 17.000 & 15.802 & 14.019 \\
\hline & Billion $(\$)$ & 8.531 & 10.063 & 10.657 \\
\hline Per Capita Crude Steel Consumption & $\mathrm{kg} /$ person & 454 & 475 & 447 \\
\hline
\end{tabular}




\section{Literature Review}

There are various types of decomposition analysis in the literature. These are generally grouped under two main headings as index decomposition analysis and SDAStructural Decomposition Analysis. Both methods are used to measure the effects of economic growth, sectoral changes and technological developments, changes in the environment, and socio-economic indicators. The additive Divisia Index method was preferred due to its suitability of analytical structure, ease of use, and straightforward interpretation of the results. Therefore, the LMDI (Logarithmic Mean Divisia Index) method developed by Ang (Ang, 2005), one of the leading index decomposition analyzes, is employed. The analyses were made with five significant factors that determine the change.

LMDI, an important index decomposition analysis, has been a popular method used to analyze energy consumption changes and the factors affecting carbon emissions in many sectors over time. Therefore, it is seen that it is used in the analysis of different sectors in many countries. For example; China [[7]-[9]], Greece [10], India [11], Pakistan ([12], Nigeria [13], Spain [14], Mexico [15], Philippines [16] ve Turkey [17]-[21]. Studies frequently use five primary factors, industrial operation, industry structure, energy structure, energy intensity, and emission factor. Some other researchers have added three other factors to examine these factors affecting GHG emissions in many industries, especially the industrial sector, such as efficiency, investment intensity research \& development [22]. Gonzalez ve Martinez [15] analyzed the factors determining the greenhouse gas emissions of 16 important sectors of the Mexican economy in 1965-2003 using the decoupling method. They state that economic activity and structural factors led to an increase in electricity generation emissions during this period. Energy density and fuel composition factors had a lowering effect on emissions. Zhang et al. [7], Emodi et al. [13], Moreover, Sumabat et al. [16] used the LMDI technique to analyze $\mathrm{CO} 2$ emissions from power generation in China, Nigeria, and the Philippines. They stated that the most important contribution to $\mathrm{CO} 2$ emissions from electricity generation is due to the effect of economic activity. On the other hand, they said that energy density reduces emissions.

Although decomposition analyzes are used in many different sectors, it is generally seen in the literature that scientific researchers are carried out in energy-intensive industries and sub-sectors. There a few studies in this field concerning Turkey. They are listed below;

Akbostanc1 et al. [17] studied Turkish manufacturing greenhouse gases covering 57 industries in Turkey from 1995 to 2001 by applying the LMDI technique and established improvements in industrial growth and energy intensity are the primary main drivers of greenhouse gas alterations. Coal is the primary determinant of fuel, while the steel and iron industries are the most polluting sectors in Turkey's industrial market, with $\mathrm{CO} 2$ emissions overwhelming the industry.

Lise [18] found that economic growth is the most crucial factor in rising $\mathrm{CO} 2$ emissions relatively rapidly in developing economies. On the other hand, the decreasing energy intensity of the economy accounted for a modest decrease in $\mathrm{CO} 2$ emissions in Turkey during the 1980-2003 period.

Akbostanc1 et al. [19] decomposed and analyzed the $\mathrm{CO} 2$ emissions of five Turkish economy sectors between 1990 and 2013. These sectors are manufacturing, electricity and heat, transport, and residential industries. They found that the main factors that cause a shift in $\mathrm{CO} 2$ emissions are energy intensity and economic activity. In altering GHG pollution, the first two sectors (Manufacturing and electricity) are the most crucial. Besides, particularly for the Manufacturing sector, the fuel mixture portion reduces $\mathrm{CO} 2$ emissions during an economic downturn.

Tunç et al. [20] also used the LMDI technique to assess the definitive factor determining carbon dioxide emissions from Turkey's three main sectors (agriculture, manufacturing, and services). To investigate the impacts of different macroeconomic policies on GHG emissions, Tunç and his colleagues decomposed and analyzed Turkey's GHG emissions for the period 1970-2006, using alterations in the production and use of various energy resources. The investigation concluded that economic growth is the most significant increase in greenhouse gases. On the other hand, energy intensity decreases $\mathrm{CO} 2$ in the periods 1980-1990 and 1995-2008, and the manufacturing system is not a significant factor in lowering carbon dioxide emissions.

Rüstemoğlu [22] attempted to determine and evaluate the factors that, using the LMDI decomposition technique increased or decreased $\mathrm{CO} 2$ emissions for Turkey and Iran between 1990 and 2011. Economic growth and the population are the key determinants of $\mathrm{CO} 2$ emissions for both nations. Surprisingly, the third crucial deciding factor in Iranian carbon emissions may be the effect of energy intensity. It has, on the other hand, a minimally reduced impact on Turkey.

Ediger and Havuz [23] used the LMDI model to investigate sectoral energy usage in the Turkish economy. While there is a clear correlation between primary energy and the GDP, studies show substantial sectoral energy use variations during 1982, 1988-1989, 1994, and 1998-2000. They stated that government policies seem to be the vital driving force for improving the relationship between the Turkish economy and the 
oil economy. Such policies would include improving the composition of final energy requirements, improving the quality of materials and energy, and replacing more acceptable products and oils. Furthermore, researchers have done much scientific investigation on the iron and steel industry of many countries.

Sun et al. [24] have paid attention to China's iron \& steel industry as a significant energy-consuming manufacturing sector and one of the most significant caused by carbon dioxide (CO) emissions. The logarithmic mean division index (LMDI) technique is used to decompose the overall change in $\mathrm{CO} 2$ emissions into four factors: the effect of the emission factor, the effect of the energy structure, energy consumption, and the effect of steel production. The findings revealed that the effects of steel production are the key factor responsible for the increase in $\mathrm{CO} 2$ emissions, while energy consumption contributes most to reducing $\mathrm{CO} 2$ emissions. Moreover, there is a weak negative contribution to the increase in $\mathrm{CO} 2$ emissions from the emission factor effect. Correlation equations are also suggested to determine the complicated relationship between the change in energy use or output of steel and $\mathrm{CO} 2$ emissions change.

Tian et al. [9] have examined the energy-related GHG emission trajectories, characteristics, and driving forces for Chinese ISI for 2001-2010. Using the logarithmic mean Divisia index (LMDI) decomposition analysis, the driving forces for such emission changes are examined. The findings indicate that the Chinese ISI has undergone a rapid increase in GHG emissions related to energy at an annual average growth rate of 70 million tons of $\mathrm{CO} 2$ eq. The output scale effect is the key driving force for the rise in GHG emissions related to Energy in the Chinese ISI. In contrast, the effect of the energy intensity effect and the effect of the emission factor adjustment compensates for the overall increase the energy structure has a marginal effect.

Hasanbeigi et al. [25] aim to examine influential factors that have influenced the steel industry's energy usage in the past. They analyze the patterns in energy use of leading medium-sized and large-sized steel enterprises in China during 2000-2030. The research also uses a refined analysis of the Logarithmic Mean Divisia Index decomposition to measure the effects of different variables in influencing past and future energy consumption trends. Their forecast outcome indicates that key steel companies' final energy usage peaks in 2020 under scenarios 1 and 2 (low and medium scrap usage) and 2015 under scenario 3 (high scrap use). The three scenarios generated with the forward-looking decomposition study for 2010-2030 show that the structural effect and the pig iron ratio play a crucial role in decreasing final energy use during 2010-2030, contrary to experience during 2000-2010.
Wang et al. [26] analyze the iron and steel (IS) industry of China since it is the largest emitter of air contaminants and plays an essential part in achieving a green economy. They have used the logarithmic mean Divisia index (LMDI) method to examine the influencing factors of the IS industry's air pollutant emissions from environmental regulatory impact dimensions, the effect of pollutant generating intensity, the effect of energy structure, the effect of technological development and the effect of economic impact. Based on China's IS industry's empirical study from 2005 to 2015, three significant findings can be summarized. First, in controlling air pollution in the IS industry, environmental policy plays a decisive role. Second, environmental legislation and technological development have inhibitory effects on emissions of air pollutants. In contrast, the intensity impact of the production of pollutants and the scale effect encourage emissions to some degree. Third, the industry's decoupling efforts have steadily shifted from weak to strong.

Khan et al. [12] have used the LMDI method to calculate changes in $\mathrm{CO} 2$ emissions in Pakistan over 1900-2017. The goal of this was to reduce the changes in $\mathrm{CO} 2$ emissions. They have used five variables: activity effect, structural effect, intensity effect, fuelmix effect, and emission factor effect. The three key factors responsible for changes in the country's overall $\mathrm{CO} 2$ emissions have been established as the effects of the activity effect, structural effect, and intensity effect. The activity impact is the largest contributor to overall changes in the level of $\mathrm{CO} 2$ emissions among all the effects. The structural effect positively affects $\mathrm{CO} 2$ emissions, reflecting a change in economic activity to more energy-intensive sectors. Nevertheless, the strength effect has a negative emission relationship, which is a sign of improvements in energy efficiency. They have concluded that policymakers should promote the diversification of the energy and production mix into more energy-efficient economic sub-sectors.

To achieve emission reduction targets for determining to make a low-carbon transition of Turkey, we conduct a specific investigation on the Turkish high-energy intensive sector, iron, and steel, for the period 19982018 by employing the LMDI method.

To achieve emission reduction targets for determining to make a low-carbon transition of Turkey, we conduct a specific investigation on the Turkish high-energy intensive sector, iron, and steel, for the period 19982018 by employing the LMDI method. 
Table 5. The change in greenhouse gas emissions in the iron and steel industry, kt CO2 eq. (1998-2018).

\begin{tabular}{cccccc}
$\Delta \mathbf{C}_{\text {act }}$ & $\Delta \mathrm{C}_{\text {str }}$ & $\Delta \mathrm{C}_{\text {int }}$ & $\Delta \mathrm{C}_{\text {mix }}$ & $\Delta \mathrm{C}_{\text {emf }}$ & $\Delta \mathrm{C}_{\text {tot }}$ \\
\cline { 2 - 5 }
\end{tabular}

Activity effect Structure effect Intensity effect Energy-mix effect Emission factor effect Total effect

\begin{tabular}{rrrrrrr}
\hline $1999-1998$ & -526 & -523 & 787 & -316 & 2 & -576 \\
$2000-1999$ & 418 & 76 & 507 & -14 & 3 & 990 \\
$2001-2000$ & -2.005 & 1.208 & -620 & 1.586 & -2 & 166 \\
$2002-2001$ & 1.068 & -186 & 59 & -1.213 & 0 & -271 \\
$2003-2002$ & 1.794 & 26 & -1.584 & -496 & -3 & -264 \\
$2004-2003$ & 1.403 & 1.555 & -2.916 & -1.177 & -5 & -1.140 \\
$2005-2004$ & 1.132 & -235 & -640 & 173 & -4 & 425 \\
$2006-2005$ & 457 & 800 & -1.221 & -983 & -11 & -958 \\
$2007-2006$ & 972 & 434 & -977 & -309 & -4 & 116 \\
$2008-2007$ & 495 & 973 & -1.144 & -986 & 0 & -662 \\
$2009-2008$ & -621 & -1.497 & 1.824 & -771 & -0 & -1.066 \\
$2010-2009$ & 491 & 152 & -75 & -838 & 3 & -268 \\
$2011-2010$ & 240 & 997 & -853 & 926 & 36 & 1.346 \\
$2012-2011$ & 188 & -172 & -27 & 366 & -46 & 308 \\
$2013-2012$ & 387 & -340 & 99 & 194 & -0 & 340 \\
$2014-2013$ & -79 & -23 & 15 & 440 & 1 & 354 \\
$2015-2014$ & -417 & -691 & 1.345 & 1.179 & -1.120 & 295 \\
$2016-2015$ & 5 & -543 & 664 & -769 & -454 & -1.097 \\
$2017-2016$ & -50 & 1.170 & -640 & -104 & -238 & 137 \\
$2018-2017$ & -331 & 874 & -569 & -129 & 39 & -115 \\
Total & $\mathbf{5 . 0 1 9}$ & $\mathbf{4 . 0 5 5}$ & $\mathbf{- 5 . 9 6 9}$ & $\mathbf{- 3 . 2 4 0}$ & $\mathbf{- 1 . 8 0 5}$ & $\mathbf{- 1 . 9 4 0}$ \\
\hline
\end{tabular}

\section{Methodology}

The LMDI method developed by Ang (Ang, 2005) was used in the formula below to determine the change in greenhouse gas emissions caused by the iron and steel industry and the effect of five factors thought to be determinant in the formation of this change

$C=\sum_{i j} C_{i j}=\sum_{i j} Q \frac{Q_{i}}{Q} \frac{E_{i}}{Q_{i}} \frac{E_{i j}}{E_{i}} \frac{C_{i j}}{E_{i j}}=\sum_{i j} Q S_{i} I_{i} M_{i j} U_{i j}$

Where $\mathrm{C}$ is the total $\mathrm{CO} 2$ emissions of the Turkish iron and steel industry; i specifies the $\mathrm{i}$-th combustion sector; $\mathrm{j}$ represents the jth type of fuel $\mathrm{Si}=\mathrm{Qi} / \mathrm{Q}$ represents the industrial structure, Ii (=Ei/Qi) represents the energy intensity of sector $\mathrm{i}$; $\mathrm{Mij}(=\mathrm{Eij} / \mathrm{Ei})$ is the fuel-mix variable, and $\mathrm{Uij}(=\mathrm{Cij} / \mathrm{Eij})$ represents the $\mathrm{CO} 2$ emissions factor of fuel $\mathrm{j}$ consumed in i sector [27].

The LMDI into the five components as illustrated;

(i) The economic activity effect ( $\Delta$ Cact);

(ii) The structure effect (shown as $\Delta$ Cstr);

(iii) The sectoral energy intensity effect (shown as $\Delta$ Cint);

(iv) The sectoral energy-mix effect (shown as $\Delta \mathrm{Cmix}$ ); and

(v) The emissions factor effect (denoted as $\Delta$ Cemf ) in additive form.

\section{Results and Discussion}

The LMDI method developed by Ang (Ang, 2005) has been applied to determine the change in greenhouse gas emissions caused by the iron and steel industry into the effect of five for the period 1998-2018.

The LMDI can be expressed as:

$\Delta \mathrm{C}_{\mathrm{act}}=\sum_{\mathrm{ij}} \frac{\mathrm{C}_{\mathrm{ij}}^{\mathrm{T}}-\mathrm{C}_{\mathrm{ij}}^{0}}{\ln \mathrm{C}_{\mathrm{ij}}^{\mathrm{T}}-\ln \mathrm{C}_{\mathrm{ij}}^{0}} \ln \left(\frac{\mathrm{Q}^{\mathrm{T}}}{\mathrm{Q}^{0}}\right)$

$\Delta \mathrm{C}_{\mathrm{str}}=\sum_{\mathrm{ij}} \frac{\mathrm{C}_{\mathrm{ij}}^{\mathrm{T}}-\mathrm{C}_{\mathrm{ij}}^{0}}{\ln \mathrm{C}_{\mathrm{ij}}^{\mathrm{T}}-\ln \mathrm{C}_{\mathrm{ij}}^{0}} \ln \left(\frac{\mathrm{S}_{i}^{\mathrm{T}}}{\mathrm{S}_{i}{ }^{0}}\right)$

$\Delta \mathrm{C}_{\mathrm{int}}=\sum_{\mathrm{ij}} \frac{\mathrm{C}_{\mathrm{ij}}^{\mathrm{T}}-\mathrm{C}_{\mathrm{ij}}^{0}}{\ln \mathrm{C}_{\mathrm{ij}}^{\mathrm{T}}-\ln \mathrm{C}_{\mathrm{ij}}^{0}} \ln \left(\frac{\mathrm{I}_{i}^{\mathrm{T}}}{\mathrm{I}_{i}{ }^{\mathrm{T}}}\right)$

$\Delta \mathrm{C}_{\text {mix }}=\sum_{\mathrm{ij}} \frac{\mathrm{C}_{\mathrm{ij}}^{\mathrm{T}}-\mathrm{C}_{\mathrm{ij}}^{0}}{\ln \mathrm{C}_{\mathrm{ij}}^{\mathrm{T}}-\ln \mathrm{C}_{\mathrm{ij}}^{0}} \ln \left(\frac{\mathrm{M}_{i j}{ }^{\mathrm{T}}}{\mathrm{M}_{i j}{ }^{0}}\right)$

$\Delta \mathrm{C}_{\mathrm{emf}}=\sum_{\mathrm{ij}} \frac{\mathrm{C}_{\mathrm{ij}}^{\mathrm{T}}-\mathrm{C}_{\mathrm{ij}}^{0}}{\ln _{\mathrm{ij}}^{\mathrm{T}}-\ln _{\mathrm{ij}}^{0}} \ln \left(\frac{\mathrm{U}_{i j}{ }^{\mathrm{T}}}{\mathrm{U}_{i j}{ }^{0}}\right)$

Table-5 shows that economic activity and structural effect increase emissions, while density, energy composition, and emission factors decrease emissions. 


\subsection{Economic activity effect:}

GDP is both an indicator of a country's economic performance and a measure of national wealth. It also shows the effect on total primary energy consumption resulting from an increase in production. Increasing economic output increases the activity effect and increases the growth rate in energy consumption. It positively contributes to the increase in energy consumption. If production falls, the economic activity effect reduces energy demand growth and negatively affects energy consumption change. The economic activity effect naturally harmed emissions in 1999, 2001, and 2009, when the economic recession (Table5). However, despite the favorable growth rates of 5.2\% in $2014,6.1 \%$ in $2015,7.5 \%$ in 2017 , and $2.8 \%$ in 2018 , there was a decrease in energy-related emissions in the iron and steel sector. This fact is related to the reduction in steel production compared to the previous year. The cumulative effect of economic activity rise of $5 \mathrm{kt} \mathrm{GHG}$ from 1998 to 2018 (Table-5).

\subsection{Sectoral Structure Effect}

The structural effect is the factor that indicates the change in the proportional value of each sector within the total economic activity (GDP). In other words, it is the change in total energy consumption resulting from the change (increase or decrease) in the total production composition of the iron and steel industry. For example, while the share of iron and steel production in GDP was $1.22 \%$ in 1999 , this value was lower than $1.24 \%$ in 2000. This result creates an emission-increasing effect for the 2000-1999 period. The iron and steel industry's share in the total production composition between 20181998 increased from $1.34 \%$ to $3.18 \%$. (Table -3) It led to a 4.0 Mtons increase in emissions due to the sectoral structure effect (Table-5).

\subsection{Sectoral energy intensity effect}

Energy density is the amount of energy used per unit output or process required. The density of the iron and steel industry is calculated as toe / $1000 \$$ in this study. Therefore, density is an indicator of the toe's energy consumed for $\$ 1000$ in the sector. It is expected that the sectors' energy density would be lower with apply advanced, effective, and efficient production techniques and make improvements in material and fuel quality. Since technological change and progress need less energy to produce the same amount of product. In other words, much more product is expected to be obtained with the same amount of energy. [28]. Therefore, while energy density increases in the early stages of the developing economy and sectors, technological developments in the developed economy and sectors reduce the energy density and make production more efficient. Many studies in recent years have shown that reducing its density limits or reduces energy-related greenhouse gas emissions. [7], [17], [19], [29]-[30].

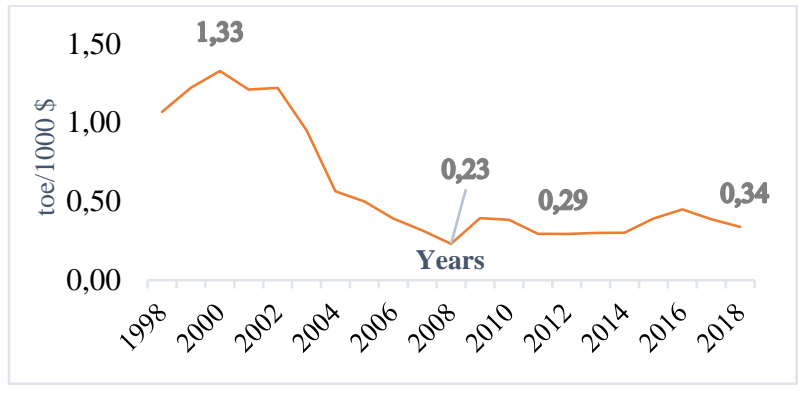

Figure 3. Energy intensity of the iron and steel industry by years (toe/1000 $\$$ ).

The iron and steel industry's energy intensity started to decline in 1999, and this trend continued until 2008 when the global economic recession occurred. The increasing intensity in 2009 started to decrease again in 2010 and 2011. Energy intensity, which has a steadystate between 2011 and 2014, started to increase in 2015 and reached the highest point of the last quarter of 2016. Since 2017, the sector has started to recover, and the energy intensity has started to decline again. Although the density effect took positive values in many years between 1998 and 2018, it generally has negative values. Especially in the period 2000-2008, the decrease in intensity significantly reduces the sectoral-based emissions. The downward trend was broken in 2009 with a high positive value. The impact of the global economic crisis in the iron and steel industry was felt seriously. Figure- 3 shows that the density effect was not very useful in the 2010-2014 period. Decreases followed the increases in 2015 and 2016 in 2017 and 2018. It was determined that in 2015 and 2016, more energy consumption and lower revenue was obtained for unit product production. In particular, Turkey's steel production showed a drop for the third time in succession in 2015, while world steel production, the global financial crisis in 2009, and then-induced decline, declined for the first time in 2015 . In the post2016 period, the sector has taken advantage of significant energy use and technologies and energysaving techniques and has managed to take the density effect to negative values (Figure-3). This improvement contributed to the reduction of the sectoral intensity effect by approximately $6.0 \mathrm{Mt}$ in total emissions. (Table-5)

\subsection{Sectoral energy mix effect}

This effect shows how industries are using existing fuels and are calculated by dividing the energy consumption of a fuel type by the total energy consumption of that sector. Until 2009, solid (coke, derived gases, hard coal) and liquid fuels (petroleum products) and a limited quantity of natural gas was widely used in the iron and steel industry. In the period 2009-2018, solid and liquid 
fuels were replaced by a high-rate of natural gas. Although this fuel composition change caused the fuel composition effect to have positive values in the 1998 2018 period, it took negative values in general. It caused the sector emissions to decrease by $3.2 \mathrm{Mt}$ in total (Table-5).

\subsection{Emission Factor Effect}

The emission factor effect, which shows the effect of the fuel efficiency used in the sector on the emissions, does not affect the sectoral emissions between 19982014. (Table -5). Since there is no change in the carbon content of the fuels used for this period, however, it is determined that the emission reductions were caused by the usage of lower emission factors of the solid fuels used in 2015, 2016, and 2017. The plant-based emission factors could not be calculated until 2015; therefore, the default values in the IPCC 2006 Guidelines were used, and facility-based EF was calculated with calculations based on elemental analysis of fuels used in Integrated Iron and Steel plants since 2015. The emission factor effect reduced emissions between 2015-2017 by applying facility-based EF (Table-5).

\section{Conclusion}

The European Green Deal, which reveals the European Union's new strategic vision for 2050 with the perspective of "combating climate change and economic growth," to increase its citizens' welfare, live in a clean and healthy environment, and secure future generations. EGD was announced in 2019, and it is a new growth strategy prepared for the European Union that would provide more than it would spend. As our most important export and import partner, the EU plans to implement carbon border regulation mechanisms against commercial partners in 2021, would require serious measures, especially for our energy-intensive sectors. Mechanisms would profoundly affect our trade. Besides, it included being a party to the Paris Agreement and fulfilling the requirements of the Agreement in all international trade agreements that the EU has recently negotiated. In the Green Deal, the EU declared that it would adopt this practice for all future trade agreements; therefore, it is anticipated that this issue would come to the agenda in updating the Customs Union, which aims to be initiated by our country. Also, considering the legislative and implementation changes envisaged by the EU in the titles of Industry, Agriculture, Transport, and Energy, it is considered that a much wider part of our exports to the EU would be affected by the EU's climate change measures. This EGD implementation, which is obvious to have the most significant impact on a global scale, both its possible effects were evaluated and discussed with the measures taken to have the least impact on our country's iron and steel industry. For this purpose, the change in the energy-related greenhouse gas emissions originating from the iron and steel industry from 1998 to 2018 was analyzed into five driving forces using the LMDI, one of the effective decomposition methods. Because of the analysis, it has been determined that the economic activity impact (GDP) is the most crucial determining factor behind the change in $\mathrm{CO} 2$ emissions. It increases the emissions by $5 \mathrm{Mt}$. The sectoral structure effect means the change in the sectors' proportional value within the total economic activity.

Furthermore, it affects that similar to economic activity and increases $4 \mathrm{Mt}$ in the specified period. The other three factors were found to reduce emissions. The sectoral energy intensity reduced emissions by about 6 Mt, followed by the energy mix effect with 3.2 million. The emission factor reduced the total emissions by around $2 \mathrm{Mt}$ in the specified period.

The steel industry is among the most energy-consuming industries in the world. Improving energy efficiency in the iron and steel sector through the presentation and implementation of the latest technologies and techniques is essential because its share of total energy consumption in Turkey, 7.5\%, and industrial consumption is around $22.9 \%$. Studies are carried out in high-energy consumption units to reduce energy consumption in the blast furnace, coke factories, arc furnace, annealing furnace, energy systems feeding the furnace, dust holding, and cooling water systems. Our steel industry's energy share in input costs ranks 2nd after raw materials and has a high ratio of around 15$25 \%$. The share of energy in production costs is sufficient to show how vital energy has for the iron and steel industry.

For this reason, our steel industry has drawn a roadmap for the development of projects that increase energy efficiency and continues to work towards renovation by continually improving its technology. In our steel industry, energy efficiency studies started in the 80s; considering the studies carried out in the last ten years; Energy consumption per ton of crude steel has been reduced by $18-20 \%$. It is necessary to speed up energy efficiency studies to ensure sustainable low carbon development. It would be beneficial to use higher technology products and encourage renewable and carbon-free gases and technologies, mainly hydrogen, by the state.

Regarding climate change, the average compared to other countries per tons of steel crude steel production in Turkey (about 1.5 tons) of $\mathrm{CO} 2$ emissions caused stated under ( 0.69 tons of $\mathrm{CO} 2)$. This result is mainly due to the predominance of electric arc furnaces in production $(69.8 \%$ of the factories are electric arc furnaces in 2014). Major producers such as Erdemir are also developing projects for energy and resource efficiency with multilateral development banks' support. These are admirable developments. However, 
in the fight against climate change went ahead to say that Turkey's steel sector would be misleading. The road to be taken is long for the sector players who are still at awareness and capacity building.

Furthermore, technological advances in reducing greenhouse gas emissions can only solve a part of the problem. Absolute mitigation measures such as reducing consumption, ensuring energy and resource efficiency, making electrification, and ensuring

\section{Author's Contributions}

Abdulkadir Bektaş: Drafted and wrote the manuscript, performed the experiment and result analysis.

\section{Ethics}

There are no ethical issues after the publication of this manuscript.

\section{References}

1. IPCC. "Proposed outline of the special report in 2018 on the impacts of global warming of $1.5^{\circ} \mathrm{C}$ above pre-industrial levels and related global greenhouse gas emission pathways, in the context of strengthening the global response to the threat of climate cha”. IPCC - Sr15 2, 17-20, 2018.

2. European Commission, Speech by President von der Leyen in the Plenary of the European Parliament at the debate on the European Green Deal https://ec.europa.eu/commission/presscorner/ detail/ en/speech_19_6751/(accessed at 21.02.2021).

3. European Commission, EU Green Deal (carbon border adjustment mechanism) https://ec.europa.eu/info/law/better-regulation/haveyour-say/initiatives/12228-Carbon-Border-AdjustmentMechanism/(accessed at 21.02.2021)

4. Claeys, G., Tagliapietra, S. and Zachmann, G. (2019) How to make the European Green Deal work", Bruegel Policy Contribution.

5. TURKSTAT (2020) Turkish Greenhouse gas inventory report 1990-2018. Ankara: TURKSTAT. Available at: https://unfccc.int/documents/223580.

6. SteelData is the largest online steel statistics bank of Turkey http://www.steel-data.com/ (accessed at 31.10.2020)

7. Zhang, M. et al. (2013) "Decomposition analysis of CO2 emissions from electricity generation in China," Energy Policy, 52, pp. 159-165. doi: 10.1016/j.enpol.2012.10.013

8. Song, Y., Huang, J. B. and Feng, C. (2018) "Decomposition of energy-related $\mathrm{CO} 2$ emissions in China's iron and steel industry: A comprehensive decomposition framework," Resources Policy. Elsevier Ltd, 59(March), pp. 103-116. doi:

9. Tian, Y., Zhu, Q. and Geng, Y. (2013) "An analysis of energyrelated greenhouse gas emissions in the Chinese iron and steel industry," Energy Policy, 56, pp. 352-361. doi:

10. Hatzigeorgiou, E., Polatidis, H. and Haralambopoulos, D. (2008) "CO 2 emissions in Greece for 1990-2002: A decomposition analysis and comparison of results using the Arithmetic Mean Divisia Index and Logarithmic Mean Divisia Index techniques," energy, 33(3), pp. 492-499. doi: 10.1016/j.energy.2007.09.014. electricity production in all processes must be implemented urgently, with fully independent of fossil fuels. The usage of renewable energy sources can achieve the best solution as they are both viable and do not damage the environment like fossil fuels and to reduce the high reliance on imported resources and to meet the envisaged 2023 goals of greenhouse gas emission reduction by using domestic energy sources.

11. Paul, S. and Bhattacharya, R. N. (2004) "CO2 emission from energy use in India: A decomposition analysis," Energy Policy, 32(5), pp. 585-593. doi: 10.1016/S0301-4215(02)00311-7.

12. Khan, A., Jamil, F. and Khan, N. H. (2019) "Decomposition analysis of carbon dioxide emissions in Pakistan," SN Applied Sciences. Springer International Publishing, 1(9), pp. 1-8. doi: 10.1007/s42452-019-1017-z.

13. Emodi, N. V. and Boo, K. J. (2015) "Decomposition analysis of $\mathrm{CO} 2$ emissions from electricity generation in Nigeria," International Journal of Energy Economics and Policy, 5(2), pp. $565-573$

14. Cansino, J. M., Sánchez-Braza, A. and Rodríguez-Arévalo, M. L. (2015) "Driving forces of Spain's CO2 emissions: A LMDI decomposition approach," Renewable and Sustainable Energy Reviews. Elsevier, 48, pp. 749-759. doi: 10.1016/j.rser.2015.04.011.

15. González, D. and Martínez, M. (2012) "Decomposition analysis of $\mathrm{CO} 2$ emissions in the Mexican industrial sector," Energy for Sustainable Development, 16(2), pp. 204-215. doi: 10.1016/j.esd.2012.01.005.

16. Sumabat, A. K. et al. (2016) "Decomposition analysis of Philippine $\mathrm{CO} 2$ emissions from fuel combustion and electricity generation," Applied Energy, 164, pp. 795-804. doi: 10.1016/j.apenergy.2015.12.023.

17. Akbostanci, E., Tunç, G. I. and Türüt-Așik, S. (2011) "CO2 emissions of Turkish manufacturing industry: A decomposition analysis," Applied Energy, 88(6), pp. 2273-2278. doi: 10.1016/j.apenergy.2010.12.076.

18. Lise, W. (2006) "Decomposition of CO 2 emissions over 19802003 in Turkey," Energy Policy, 34(14), pp. 1841-1852. doi: 10.1016/j.enpol.2004.12.021.

19. Akbostancı, E., Tunç, G. İ. and Türüt-Aşık, S. (2018) "Drivers of fuel based carbon dioxide emissions: The case of Turkey," Renewable and Sustainable Energy Reviews, 81(July 2017), pp. 2599-2608. doi: 10.1016/j.rser.2017.06.066.

20. Ipek Tunç, G., Türüt-Aşik, S. and Akbostanci, E. (2009) “A decomposition analysis of $\mathrm{CO} 2$ emissions from energy use: Turkish case," Energy Policy, 37(11), pp. 4689-4699. doi: 10.1016/j.enpol.2009.06.019

21. Rüstemoğlu, H. (2016) "Environmental costs of economic growth : Determinants of CO2 emissions in Turkey and Iran," pp. 2151-2168Shao, S. et al. (2016) "Using an extended LMDI model to explore techno-economic drivers of energy-related industrial CO2 emission changes: A case study for Shanghai (China)," Renewable and Sustainable Energy Reviews. Elsevier, 55, pp. 516-536. doi: 10.1016/j.rser.2015.10.081.

22. Shao, S. et al. (2016) "Using an extended LMDI model to explore techno-economic drivers of energy-related industrial CO2 emission changes: A case study for Shanghai (China)," Renewable and Sustainable Energy Reviews. Elsevier, 55, pp. 516-536. doi: 10.1016/j.rser.2015.10.081.Ediger, V. Ş. and 
Huvaz, O. (2006) "Examining the sectoral energy use in Turkish economy (1980-2000) with the help of decomposition analysis," Energy Conversion and Management, 47(6), pp. 732-745. doi: 10.1016/j.enconman.2005.05.022.

23. Ediger, V. Ş. and Huvaz, O. (2006) "Examining the sectoral energy use in Turkish economy (1980-2000) with the help of decomposition analysis," Energy Conversion and Management, 47(6), pp. 732-745. doi: 10.1016/j.enconman.2005.05.022.

24. Sun, W. qiang et al. (2011) "Change in Carbon Dioxide (CO2) Emissions From Energy Use in China's Iron and Steel Industry," Journal of Iron and Steel Research International. Elsevier, 18(6), pp. 31-36. doi: 10.1016/S1006-706X(11)60074-5.

25. Hasanbeigi, A., Jiang, Z. and Price, L. (2014) "Retrospective and prospective analysis of the trends of energy use in Chinese iron and steel industry," Journal of Cleaner Production. Elsevier Ltd, 74(2014), pp. 105-118. doi: 10.1016/j.jclepro.2014.03.065.

26. Wang, X. et al. (2020) "Factor decomposition and decoupling analysis of air pollutant emissions in China's iron and steel industry," Environmental Science and Pollution Research. Environmental Science and Pollution Research, 27(13), pp. 15267-15277. doi: 10.1007/s11356-020-07997-w.

27. Ang, B. W. (2004) "Decomposition analysis for policymaking in energy: Which is the preferred method?," Energy Policy. Elsevier BV, 32(9), pp. 1131-1139. doi: 10.1016/S0301-4215(03)00076-4.

28. $\mathrm{Du}, \mathrm{G}$. et al. (2018) "A decomposition analysis of energy-related CO2 emissions in Chinese six high-energy intensive industries," Journal of Cleaner Production, 184, pp. 1102-1112. doi 10.1016/j.jclepro.2018.02.304.

29. Wang, C., Chen, J. and Zou, J. (2005b) "Decomposition of energy-related CO2 emission in China: 1957-2000," energy. doi: 10.1016/j.energy.2004.04.002.

30. Lin, B. and Tan, R. (2017) "Sustainable development of China's energy intensive industries: From the aspect of carbon dioxide emissions reduction," Renewable and Sustainable Energy Reviews. Elsevier Ltd, 77(February), pp. 386-394. doi: 10.1016/j.rser.2017.04.042. 